\title{
Wpływ zanieczyszczenia olejem napędowym na uziarnienie i plastyczność mad z rejonu Warszawa-Siekierki
}

\author{
Dorota Izdebska-Mucha ${ }^{1}$, Jerzy Trzciński ${ }^{1,2}$, Marta Klein ${ }^{1}$
}

\begin{abstract}
The effect of diesel fuel contamination on the particle size distribution and plasticity of muds from the area of Warsaw-Siekierki. Prz. Geol., 69: 800-810; doi: 10.7306/2021.42

A b s t r a c t. The paper presents the results of testing flood facies sediments-muds. The term "muds" refers to a genetic type of deposits, regardless of their variability in particle size composition and organic matter content. Due to the poor geological engineering properties, such as, high lithological variability, low degree of diagenesis, as well as high moisture content and organic matter content, muds are classified as weak soils and river valleys are the areas of complicated ground conditions. The paper presents lithological, physical and chemical properties of muds from the floodplain of the Vistula River valley in the area of Warsaw-Siekierki. A series of mud samples contaminated with diesel fuel in the range of 2-16\% were prepared. The microaggregate analyses as well as the plastic and liquid limit tests showed a significant effect of contamination on the soil index properties. The increase in diesel fuel content resulted in the loss of soil plasticity and cohesion. The aggregation of clay particles and the increase in the silt fraction content was observed. The most significant changes of properties were obtained for the mud samples containing 6-16\% of diesel fuel. The research of soils contaminated with petroleum products is of great importance in determining the geological engineering conditions of the subsoil for foundation purposes.
\end{abstract}

Keywords: Vistula valley, alluvial soils, geological engineering properties,petroleum products, contaminated sites, foundation conditions

Mady to termin genetyczny powszechnie używany do charakterystyki osadów aluwialnych facji powodziowej akumulowanych w dolinach, a szczególnie w starorzeczach i deltach. W praktyce geologiczno-inżynierskiej i geotechnicznej osady takie są określane wg polskiej normy PN-B-02480:1986 nazwą namuły (Nm), które z dodatkiem frakcji piaskowej są określane namułami piaszczystymi - Nmp, a z dodatkiem frakcji iłowej namułami gliniastymi - Nmg. Mady są wyróżniane wśród osadów dolin rzecznych niezależnie od składu granulometrycznego i zawartości substancji organicznej (Myślińska, 2001). Zgodnie z PN-B-02480 (1986) osady te są zaliczane do grupy gruntów nieskalistych organicznych (zawartość części organicznych $>2 \%$ ). Mady charakteryzują się zróżnicowaną litologią wynikającą ze zmiennych warunków sedymentacji, w szczególności zmienną zawartością substancji organicznej, która najczęściej nie przekracza $10 \%$. W Polsce osady te budują holoceńskie tarasy zalewowe i nadzalewowe dolin rzecznych oraz tarasy plejstoceńskie większych rzek, zajmując ponad $7870 \mathrm{~km}^{2}$, co stanowi ok. 5\% powierzchni kraju. Miąższość jaką osiągają mady to 1-2 $\mathrm{m}$ na tarasach holoceńskich, natomiast na tarasach plejstoceńskich najczęściej jest to 3-4 m. Mady zajmują największą powierzchnię i osiagają najwyższe miąższości w dolinach Wisły i Odry (Myślińska, 2001).

Mady ze względu na właściwości geologiczno-inżynierskie są gruntami słabymi pod względem ich nośności (słabonośnymi), na co zwraca uwagę wielu autorów, m.in. Grabowska-Olszewska, Siergiejew (1977), Myślińska (1984, 2016), Gontaszewska (2010) oraz Kaczyński (2017). Wynika to przede wszystkim z dużej zmienności cech litologicznych, niskiego stopnia diagenezy oraz wysokiej wilgotności i zawartości substancji organicznej. Według rozporządzenia Ministra Transportu, Budownictwa i Gospodarki Morskiej z dnia 27 kwietnia 2012 r. w sprawie ustalania geotechnicznych warunków posadowienia obiektów budowlanych (Rozporządzenie, 2012) obszary dolin rzecznych należą do trzeciej kategorii - są to tereny o skomplikowanych warunkach gruntowych. Na podstawie wieloletnich badań budowy dolin rzecznych wyróżniono mady serii I gliniaste, powstałe jako osady powodziowe rzeki meandrującej o spokojnym przepływie (Falkowski, 1967, 1970, 1980). Drugim typem wyróżnionym przez tego autora są mady serii II pylasto-piaszczyste, jako osady rzeki dzikiej, roztokowej o szybkim przepływie. Zostały wydzielone również mady serii III - mady przemysłowe - jako osady antropogeniczne powstałe w wyniku zmiany naturalnych warunków sedymentacji na skutek przemysłowej działalności człowieka (Szczepankiewicz, 1974).

Zagadnienia mad i innych osadów dolin rzecznych podejmowano w literaturze pod wieloma aspektami. Frankowski (1980) określił właściwości mad wiślanych wyższego tarasu zalewowego Wisły jako gruntów słabonośnych oraz przeprowadził szereg prac polowych i laboratoryjnych, mających na celu kompleksową ocenę właściwości geologiczno-inżynierskich osadów facji powodziowej. Myślińska (1980, 1984) oraz Myślińska i in. (1982) podali kryteria oceny oraz scharakteryzowali pod względem inżyniersko-geologicznym mady doliny Wisły i jej dopływów: Bugu i Sanu (m.in. okolice Annopola, Warszawy, Grudziądza, Leżajska oraz Broku i Gródka). Wyróżnili na tych obszarach (za Falkowskim, 1967) dwie serie mad: serię I gliniastą oraz serię II piaszczysto-pylastą. Ponadto wykazali, że zróżnicowane warunki sedymentacji mają wpływ na zmienność składu granulometrycznego mad w profilu

\footnotetext{
${ }^{1}$ Wydział Geologii, Uniwersytet Warszawski, ul. Żwirki i Wigury 93, 02-089 Warszawa; dizdebsk@uw.edu.pl, jerzy.trzcinski@uw.edu.pl,martaklein@interia.pl

2 Instytut Archeologii, Uniwersytet Kardynała Stefana Wyszyńskiego, ul. Wóycickiego 1/3, 01-938 Warszawa; jerzy.trzcinski59@gmail.com
} 
pionowym i poziomym, a głównym czynnikiem wpływającym na uziarnienie jest litologia osadów budujących obszary alimentacyjne różnych odcinków doliny rzecznej. W Polsce S i SE, gdzie obszar alimentacyjny rzek, głównie Wisły i Odry, jest pokryty przez osady pylaste (lessy) oraz ilaste miocenu morskiego, występują mady bardziej drobnoziarniste. Natomiast środkowe i północne odcinki tych rzek, gdzie obszary alimentacyjne są pokryte polodowcowymi osadami gliniasto-piaszczystymi, występują mady bardziej gruboziarniste (Myślińska, 2001). Zależności parametrów gęstościowych od zawartości substancji organicznej dla gruntów organicznych i mineralnych z okolic Białej Podlaskiej i Kurowa, m.in. mad, określił Stępień (1996). Wójcik (2003) zbadała zależności pomiędzy ciśnieniem ssania a parametrami geologiczno-inżynierskimi oraz przepuszczalnością gruntów z terenu Warszawy, w tym również mad. Falkowska (2005) badała związki akumulacji metali ciężkich w osadach facji powodziowej z morfologią doliny Wisły na odcinku od Annopola do Gołębia. Wyniki przeprowadzonych badań pozwoliły stwierdzić, że najwyższa akumulacja metali ciężkich wstępuje w strefach najszerszej doliny, w madach stanowiących przewarstwienia piaszczystych utworów facji korytowej. Roman i in. (2016) scharakteryzowali warunki geologiczno-inżynierskie tarasu zalewowego Warty w rejonie Uniejowa, gdzie znaczny udział w budowie doliny mają słabonośne grunty organiczne i mady, które nie mogą być podłożem większych obiektów budowlanych.

Badany przez autorów obszar doliny Wisły udokumentowano na podstawie opracowań geotechnicznych wykonanych w związku prowadzonymi w tym rejonie inwestycjami budowlanymi (np. Geoprojekt, 1997a, b; Kociszewski, 2003, 2004). Szczegółowa charakterystyka parametrów litologicznych, fizycznych i mechanicznych mad z tego obszaru (poletko Bluszczańska-Trasa Siekierkowska) została również wykonana podczas realizacji projektu badawczego dotyczącego geologiczno-inżynierskiej ocena statycznego i dynamicznego zachowania się gruntów występujących w przekroju doliny Wisły w Warszawie na wysokości Mokotów-Ursynów. Projekt ten zrealizowano na Wydziale Geologii Uniwersytetu Warszawskiego (Kaczyński i in., 2009-2012).

Tematyka zanieczyszczeń środowiska gruntowo-wodnego produktami ropopochodnymi jest niezwykle aktualna ze względu na postępujące w szybkim tempie procesy urbanizacji, w tym rozwój przemysłu, infrastruktury drogowej oraz dystrybucji paliw. Miejscami, które stanowia potencjalne zagrożenie są m.in: rafinerie, stacje paliw, rurociagi, magazyny, bazy przeładunkowe, komunalni użytkownicy, a także wszelkiego rodzaju awarie czy wycieki paliw (np. Surygała, Śliwka, 1999; Izdebska-Mucha, Trzciński 2007, 2011). Produkty ropopochodne przyczyniają się do zagrożenia życia organizmów żywych oraz funkcjonowania ekosystemów na terenach skażonych tymi substancjami, a zanieczyszczone środowisko gruntowo-wodne wykazuje niekorzystne zmiany parametrów geologiczno-inżynierskich (np. Ostap, 2010; Khosravi i in., 2013; Oluremi, Osuolale, 2014; Stajszczak, 2021).

Zanieczyszczenie obszarów dolin rzecznych produktami ropopochodnymi, na których występują mady, jest zagadnieniem istotnym szczególnie dla miejscowości tam zlokalizowanych. Do planów zagospodarowania przestrzennego coraz częściej są włączane takie obszary, jako tereny inwestycyjne, co powoduje potencjalne narażenie środowiska gruntowo-wodnego na zanieczyszczenie tymi produktami. Dlatego głównym celem pracy jest określenie wpływu zanieczyszczenia olejem napędowym na podstawowe, wskaźnikowe właściwości geologiczno-inżynierskie mad, takie jak uziarnienie i plastyczność. Autorzy artykułu prezentują szersze spektrum właściwości mad naturalnych z obszaru Warszawa-Siekierki, a mianowicie cechy litologiczne, parametry fizyczne oraz chemiczne. Badaniom poddano mady naturalne (niezanieczyszczone) oraz pasty przygotowane $\mathrm{z}$ tych gruntów, które zostały zanieczyszczone olejem napędowym w warunkach laboratoryjnych. Jako zanieczyszczenie wybrano olej napędowy ze względu na powszechne użytkowanie tego paliwa.

\section{MATERIALY I METODYKA BADAŃ}

Próbki mad do badań laboratoryjnych zostały pobrane w dolinie Wisły na terenie lewobrzeżnej części Warszawy, przy al. Józefa Becka, stanowiącej lewobrzeżną część Trasy Siekierkowskiej (ryc. 1A). Obszar badań jest położony w obrębie wyższego tarasu zalewowego, występującego po obu stronach Wisły oraz w dolinach jej dopływów. Taras ten największą powierzchnię zajmuje na terenie Warszawa-Siekierki i w rejonie Osiedla Las, gdzie osiaga szerokość $3 \mathrm{~km}$. Starorzecza, jakie zachowały się na terenie tarasu, to Jeziorko Czerniakowskie i Wilanowskie (Sarnacka, 1979, 1980, 1992).

Próbki gruntu do badań laboratoryjnych zostały pobrane za pomocą cylindrów typu Shelby z wiercenia wykonanego w ramach projektu badawczego 3629/B/T02/2009/37 (Kaczyński i in., 2009-2012). W profilu pionowym podłoża stwierdzono występowanie mad gliniastych o miąższości ok. 3,5 m, podścielonych piaskami facji korytowej (ryc. 1B). Próbki gruntu o naruszonej i nienaruszonej strukturze pobrano na głębokości $1,5 \mathrm{~m}$. Na podstawie opisu makroskopowego potwierdzono przynależność litologiczną badanych gruntów do mad serii I. Według PN-B-04481 (1988) badany grunt to glina pylasta zwięzła $\left(\mathrm{G}_{\pi z}\right)$ barwy brązowej, wilgotna, bezwapnista, w stanie plastycznym. Według PN-EN ISO 14688-1:2018-5 grunt określono jako ił z pyłem (siCl) barwy brązowej, bezwapnisty, o konsystencji plastycznej.

Skład mineralny oznaczono metodą analizy termicznej DTA-TG, z wykorzystaniem aparatu Q600 firmy TA Instruments. Interpretację ilościową wyników przeprowadzono wg metodyki Wyrwickiego (1996). Zawartość substancji organicznej została określona na podstawie analizy termicznej, metodą Tiurina opisaną przez Myślińską (2016) oraz metodą strat prażenia wg PN-B-04481 (1988). Zastosowano temperaturę prażenia $440^{\circ} \mathrm{C}$ zgodnie z zaleceniami PN-EN 1997-2:2009. Gęstość właściwą szkieletu gruntowego $\left(\rho_{\mathrm{s}}\right)$ pomierzono z zastosowaniem piknometru helowego AccuPyc 1330 (Micromeritics, USA). Gęstość objętościową gruntu $(\rho)$ wyznaczono metodą wyporu hydrostatycznego w ciekłej parafinie z użyciem zestawu do badania gęstości cieczy i ciał stałych (Radwag, Polska). Pojemność sorpcyjną (MBC) oraz powierzchnię właściwą $\left(\mathrm{S}_{\mathrm{t}}\right)$ wyznaczono metodą sorpcji błękitu metylenowego wg PN-B-04481 (1988), a na podstawie korelacji podanej przez Piaskowskiego (1984) obliczono powierzchnię zewnętrzną $\left(\mathrm{S}_{\mathrm{e}}\right)$ oraz pojemność wymiany kationowej (CEC). Oznaczenie wskaźnika pęcznienia $\left(\varepsilon_{\mathrm{p}}\right)$ przeprowadzono w pęcznieniomierzu zgodnie z metodyką podaną przez Myślińską (2016), na 


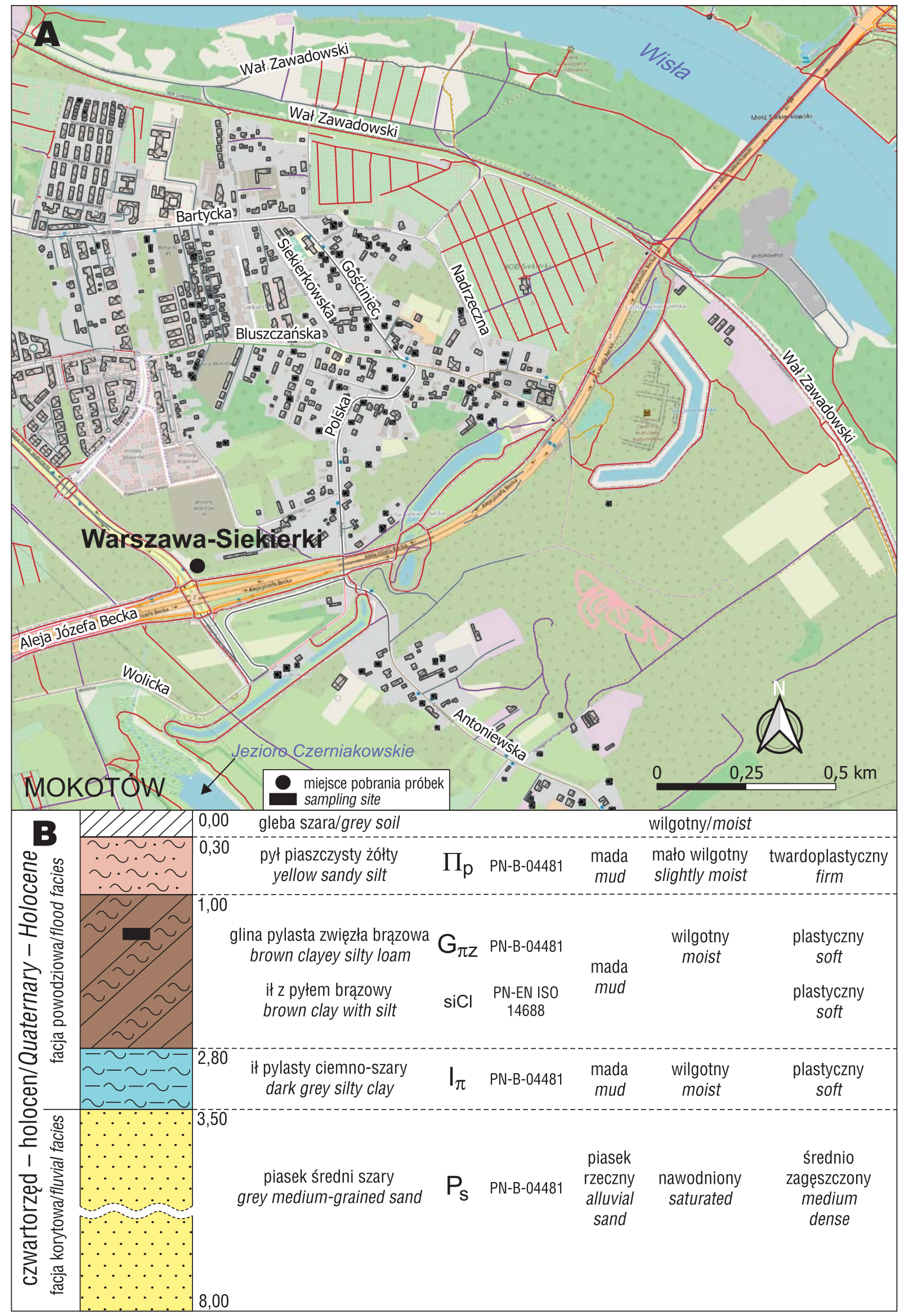

Ryc. 1. Lokalizacja badań terenowych: A - fragment mapy Warszawy z zaznaczonym rejonem Warszawa-Siekierki, B - profil geologiczno-inżynierski (Kaczyński i in., 2009-2012; zmieniony)

Fig. 1. Location of the research area: $\mathbf{A}$ - fragment of the map of Warsaw with the area of Warsaw-Siekierki marked, B - geological engineering profile (based on Kaczyński et al., 2009-2012; modified) 
Tab. 1. Parametry fizyczne oleju napędowego Ekodiesel Ultra (https://www.orlen.pl/content/dam/internet/orlen/pl/pl/dla-biznesu/produkty/ paliwa/olej-napedowy/Olej_napedowy_handlowy.pdf)

Table 1. Physical parameters of diesel fuel Ekodiesel Ultra (https://www.orlen.pl/content/dam/internet/orlen/pl/pl/dla-biznesu/produkty/ paliwa/olej-napedowy/Olej_napedowy_handlowy.pdf)

\begin{tabular}{|l|l|}
\hline \multicolumn{1}{|c|}{$\begin{array}{c}\text { Parametr } \\
\text { Parameter }\end{array}$} & \multicolumn{1}{c|}{$\begin{array}{c}\text { Wartość } \\
\text { Value }\end{array}$} \\
\hline $\begin{array}{l}\text { Poczatkowa temperatura wrzenia } \\
\text { i zakres temperatur wrzenia }\left[{ }^{\circ} \mathrm{C}\right] \\
\text { Initial boiling point and boiling range }\end{array}$ & $\begin{array}{l}175-180^{\circ} \mathrm{C}-\text { poczatkowa temperatura } \\
\text { wrzenia; } 95 \% \text { obj. destyluje do } 360^{\circ} \mathrm{C} \\
175-180^{\circ} \mathrm{C}-\text { initial boiling point; } \\
95 \% \text { vol. distills up to } 360^{\circ} \mathrm{C}\end{array}$ \\
\hline $\begin{array}{l}\text { Gestość } \mathrm{w} 15^{\circ} \mathrm{C}\left[\mathrm{g} / \mathrm{cm}^{3}\right] \\
\text { Density at } 15^{\circ} \mathrm{C}\end{array}$ & $0,82-0,845$ \\
\hline $\begin{array}{l}\text { Rozpuszczalność } \\
\text { Water solubility }\end{array}$ & $\begin{array}{l}\text { nierozpuszczalna w wodzie } \\
\text { insoluble }\end{array}$ \\
\hline $\begin{array}{l}\text { Lepkość kinematyczna } \mathrm{W} 40^{\circ} \mathrm{C}\left[\mathrm{mm}^{2} / \mathrm{s}\right] \\
\text { Kinematic viscosity at } 40^{\circ} \mathrm{C}\end{array}$ & $2,0-4,5$ \\
\hline $\begin{array}{l}\text { Stała dielektryczna }[-] \\
\text { Dielectric constant }\end{array}$ & $2,1 *$ \\
\hline
\end{tabular}

* https://krohne.com/en/services/dielectric-constants; data dostępu 09.08.2021 r.

próbkach o naruszonej strukturze, sproszkowanych, powietrzno-suchych, pod obciążeniem pionowym $1,5 \mathrm{kPa}$.

Badania składu granulometrycznego oraz parametrów konsystencji przeprowadzono na próbkach mad zanieczyszczonych w warunkach laboratoryjnych olejem napedowym (Ekodiesel Ultra, Orlen). Olej napędowy (ON) jest mieszaniną węglowodorów o długości łańcucha węglowego $\mathrm{C}_{9}-\mathrm{C}_{25}$ (https://www.orlen.pl/content/dam/internet/orlen/ pl/ pl/dla-biznesu/produkty/paliwa/olej-napedowy/Olej_napedowy_handlowy.pdf). W porównaniu do wody charakteryzuje się niższą gęstością, wyższą lepkością oraz bardzo niską wartością stałej dielektrycznej (tab. 1).

Przygotowanie próbek gruntu zanieczyszczonego ON (past gruntowych) polegało na wstępnym rozdrobnieniu oraz wysuszeniu gruntu w temperaturze $105-110^{\circ} \mathrm{C}$. Następnym etapem było roztarcie i przesianie gruntu przez sito o wymiarze oczek $2 \mathrm{~mm}$. Tak przygotowany i ujednolicony materiał został podzielony na 7 części, z których jedna stanowiła próbkę referencyjną $0 \% \mathrm{ON}$, a pozostałe zostały wymieszane $\mathrm{z}$ olejem napędowym $\mathrm{w}$ takiej ilości, aby zawartość ON wynosiła $2,4,6,8,12$ i 16\% wagowych w stosunku do suchej masy gruntu. Zanieczyszczone próbki przechowywano przez okres 4 miesięcy w szczelnie zamkniętych słoikach i mieszano raz w tygodniu, aby uzyskać jednolite pasty. Przyjęta procedura jest zgodna z metodyką stosowaną $\mathrm{w}$ tego typu badaniach, a okres homogenizacji dostateczny, aby została osiagnięta równowaga procesów pomiędzy szkieletem mineralnym a substancją ropopochodną (np. Khamehchiyan i in., 2007; Khosravi i in., 2013; Harsh i in., 2016). W miarę upływu czasu zaobserwowano, że im większe stężenie ON, tym próbki stawały się bardziej pulchne, zajmując tym samym nieco większą

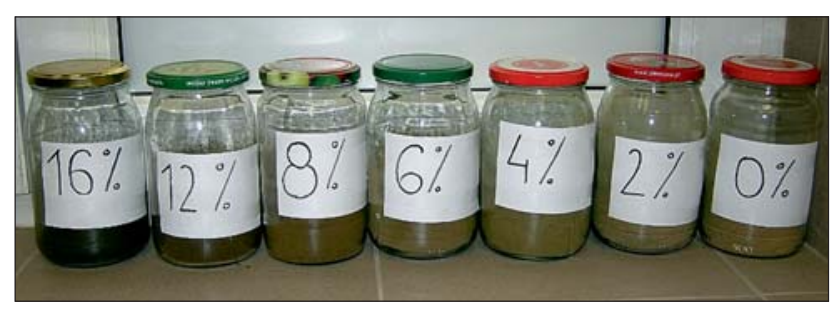

Ryc. 2. Seria próbek mad zanieczyszczonych olejem napędowym Fig. 2. Samples of muds contaminated with diesel fuel objętość w słoikach oraz charakteryzowały się ciemniejszą barwą (ryc. 2).

Badania składu granulometrycznego próbek naturalnych (niezanieczyszczonych) przeprowadzono metodą areometryczną wg PN-B-04481 (1988) oraz metodą mikroagregatową. Próbki do analizy mikroagregatowej zostały przygotowane wg metody Kaczynskiego podanej przez Myślińską (2016). Zawiesiny gruntowe przemyto przez sito o wymiarach oczek $0,063 \mathrm{~mm}$, co stanowiło modyfikację procedury Kaczynskiego, a dalsze pomiary przeprowadzono zgodnie z metodą analizy areometrycznej. Badania składu granulometrycznego past gruntowych $0-16 \%$ ON przeprowadzono metodą mikroagregatowa. Zgodnie z metodyką analizy mikroagregatowej nie stosuje się zabiegów służących rozbiciu mikroagregatów występujących $\mathrm{w}$ gruncie, zatem uzyskane wyniki obrazują naturalny stan uziarnienia i zagregowanie fazy stałej gruntu. Dzięki temu możliwe było lepsze poznanie wpływu zanieczyszczeń ropopochodnych na uziarnienie gruntu. Wszystkie analizy sedymentacyjne zostały uzupełnione analizą sitową frakcji $>0,063 \mathrm{~mm}$. Interpretacji wyników pomiarów dokonano wg normy PN-B-0248 (1986) i PN-EN ISO 14688. Oznaczenie granicy plastyczności $\left(\mathrm{w}_{\mathrm{P}}\right)$ wykonano metodą wałeczkowania wg PN-B-04481 (1988), a granicy płynności $\left(\mathrm{w}_{\mathrm{L}}\right)$ metoda penetrometru stożkowego (ELE, UK) wg BS1377: Part 2: 1990: 4.3. Do badań stosowano wodę dejonizowaną. Oznaczenia wilgotności zostały przeprowadzone wg standardowej procedury zgodnej z PN-B-04481 (1988). Próbki suszono do stałej masy, biorąc pod uwagę wydłużony czas suszenia gruntu zanieczyszczonego węglowodorami (Salimnezhad i in., 2021).

\section{WYNIKI I ANALIZA BADAŃ}

\section{Właściwości mad naturalnych (niezanieczyszczonych)}

Wyniki analizy składu mineralnego wykazały, że badane mady zawierają: $29 \%$ minerałów ilastych, $w$ tym beidelit stanowi $22 \%$, a kaolinit 7\%; ok. $1,5 \%$ substancji organicznej i ok. 0,5\% węglanów. Zawartość minerałów nieaktywnych termicznie (kwarc, skalenie, minerały ciężkie) oszacowano na $69 \%$. Wyraźna dominacja minerału ilastego z grupy smektytu potwierdza wyniki badań składu mineralnego mad przedstawione przez Myślińską (1984).

Zawartość substancji organicznej oznaczona metoda Tiurina jest zgodna $\mathrm{z}$ wynikami analizy termicznej i wynosi $1,5 \%$, natomiast metodą strat prażenia uzyskano wynik dwukrotnie wyższy $-3,2 \%$. W przypadku badania gruntów o niskiej zawartości części organicznych za bardziej miarodajne należy przyjąć wyniki uzyskane metodą Tiurina i analizy termicznej, ponieważ oznaczenie strat prażenia jest obarczone błędami związanymi z przemianami części mineralnej gruntu.

Charakterystykę podstawowych parametrów fizykochemicznych oraz wskaźnika pęcznienia badanych mad przedstawiono w tabeli 2 . Wartości tych parametrów zależą przede wszystkim od składu granulometrycznego, składu mineralnego (szczególnie frakcji iłowej) oraz zawartości substancji organicznej. Uzyskane rezultaty badań są zgodne z wartościami parametrów mad serii I z rejonu Warszawy 
Tab. 2. Podstawowe parametry fizykochemiczne oraz wskaźnik pęcznienia mad z rejonu Warszawa-Siekierki

Table 2. Basic physicochemical parameters and the expansion index of muds from the area of Warsaw-Siekierki

\begin{tabular}{|c|c|c|}
\hline & $\begin{array}{l}\text { Parametr } \\
\text { Parameter }\end{array}$ & $\begin{array}{l}\text { Wartość } \\
\text { Value }\end{array}$ \\
\hline \multicolumn{2}{|c|}{$\begin{array}{l}\text { Wilgotność naturalna } \mathrm{w}_{\mathrm{n}}[\%] \\
\text { Natural moisture content }\end{array}$} & 29,5 \\
\hline \multicolumn{2}{|c|}{$\begin{array}{l}\text { Gęstość właściwa szkieletu gruntowego } \rho_{\mathrm{s}}\left[\mathrm{Mg} / \mathrm{m}^{3}\right] \\
\text { Specific density }\end{array}$} & 2,69 \\
\hline \multicolumn{2}{|c|}{$\begin{array}{l}\text { Gesstość objętościowa gruntu }\left[\mathrm{Mg} / \mathrm{m}^{3}\right] \\
\text { Bulk density }\end{array}$} & 1,89 \\
\hline \multicolumn{2}{|c|}{$\begin{array}{l}\text { Gesstość objętościowa szkieletu gruntowego } \rho_{\mathrm{d}} \\
{\left[\mathrm{Mg} / \mathrm{m}^{3}\right]} \\
\text { Dry density }\end{array}$} & 1,46 \\
\hline \multicolumn{2}{|c|}{$\begin{array}{l}\text { Porowatość n [\%] } \\
\text { Porosity }\end{array}$} & 45,7 \\
\hline \multicolumn{2}{|c|}{$\begin{array}{l}\text { Wskaźnik porowatości e [-] } \\
\text { Void ratio }\end{array}$} & 0,84 \\
\hline \multicolumn{2}{|c|}{$\begin{array}{l}\text { Pojemność sorpcyjna }[\mathrm{g} / 100 \mathrm{~g}] \\
\text { Methylene blue capacity MBC }\end{array}$} & 5,15 \\
\hline \multicolumn{2}{|c|}{$\begin{array}{l}\text { Powierzchnia właściwa } \mathrm{S}_{\mathrm{t}}\left[\mathrm{m}^{2} / \mathrm{g}\right] \\
\text { Specific surface area }\end{array}$} & 108 \\
\hline \multicolumn{2}{|c|}{$\begin{array}{l}\text { Pojemność wymiany kationowej [meq/100g] } \\
\text { Cation exchange capacity CEC }\end{array}$} & 13,8 \\
\hline \multicolumn{2}{|c|}{$\begin{array}{l}\text { Powierzchnia zewnetrzna } \mathrm{S}_{\mathrm{e}}\left[\mathrm{m}^{2} / \mathrm{g}\right] \\
\text { External surface area }\end{array}$} & 21,8 \\
\hline \multirow{5}{*}{$\begin{array}{l}\text { Pęcznienie } \\
\text { Swelling }\end{array}$} & $\begin{array}{l}\text { wilgotność początkowa } \mathrm{w}_{0}[\%] \\
\text { initial moisture content }\end{array}$ & 2,4 \\
\hline & $\begin{array}{l}\text { gesstość objettościowa gruntu } \\
\text { poczatkowa } \rho_{0}\left[\mathrm{Mg} / \mathrm{m}^{3}\right] \\
\text { initial bulk density } \\
\end{array}$ & 1,31 \\
\hline & $\begin{array}{l}\text { wilgotność końcowa } \mathrm{w}_{\mathrm{f}}[\%] \\
\text { final moisture content }\end{array}$ & 43,3 \\
\hline & $\begin{array}{l}\text { gęstość objętościowa gruntu } \\
\text { końcowa } \rho_{\mathrm{f}}\left[\mathrm{Mg} / \mathrm{m}^{3}\right] \\
\text { final bulk density }\end{array}$ & 1,74 \\
\hline & $\begin{array}{l}\text { wskaźnik pęcznienia } \varepsilon_{\mathrm{p}}[\%] \\
\text { expansion index }\end{array}$ & 8,4 \\
\hline
\end{tabular}

podanymi przez Myślińską i in. (1982). Badane mady charakteryzują się typową dla tego rodzaju osadów wysoką wartością wilgotności, porowatości/wskaźnika porowatości oraz niską wartością gęstości objętościowej gruntu. Niskie wartości parametrów sorpcyjnych znajdują swoje odzwierciedlenie w wynikach badania pęcznienia, gdzie wartości wilgotności końcowej i wskaźnika pęcznienia sugerują niski potencjał do zmian objętościowych i niską hydrofilność badanego gruntu.

Badania składu granulometrycznego przeprowadzono dla dwóch próbek, a wyniki podane w tabeli 3 stanowią ich wartości średnie. Na rycinie 3 przedstawiono wykresy uziarnienia jednej z próbek. Wyniki badań metodą areometryczną wykazały, że według PN-B-0248 (1986) badana mada reprezentuje ił (I) blisko granicy $z$ gliną zwięzłą $\left(G_{z}\right)$. Najnowsze wydanie PN-EN ISO 14688: 2018-05 nie podaje propozycji klasyfikacji granulometrycznej gruntów na podstawie uziarnienia. Natomiast zamieszczony w PN-EN ISO 14688-2:2006/Ap2:2012 przykład możliwej klasyfikacji gruntów opartej tylko na uziarnieniu pozwala zakwalifikować badane mady jako ił z piaskiem i pyłem (sasiCl) blisko granicy iłu z pyłem ( $\mathrm{siCl}$ ). Analiza mikroagregatowa wykazała spadek zawartości frakcji iłowej o 5\%, a frakcji piaskowej o 12-15\% oraz wzrost zawartości frakcji pyłowej o 17-20\% w stosunku do wyników badań metodą areometryczną (tab. 3). Nazwy gruntu oparte na składzie $\mathrm{z}$ analizy mikroagregatowej zostały jednoznacznie określone wg obu systemów klasyfikacyjnych i odpowiadają nazwom wyznaczonym w badaniu makroskopowym (ryc. 1): glina pylasta zwięzła $\left(\mathrm{G}_{\pi z}\right)$ wg PN-B-0248 (1986) oraz ił z pyłem (siCl) wg PN-EN ISO 14688-2:2006/Ap2:2012.

W świetle dyskusji na temat możliwości przełożenia stosowanej dotychczas klasyfikacji (nazewnictwa) gruntów wg PN-B-0248 (1986) na nazewnictwo i symbolikę wg standardu europejskiego (np. Gołębiewska, Wudzka, 2006; Gołębiewska, 2011; Kowalska i in., 2017; Tarnawski, 2017) warto zwrócić uwagę, że w badanym gruncie zawartość

Tab. 3. Skład granulometryczny i nazwa próbek mad naturalnych oznaczone metodą areometryczną i mikroagregatową

Table 3. Particle size distribution and the name of the natural mud samples determined by the hydrometer and microaggregate methods

\begin{tabular}{|c|c|c|c|c|}
\hline \multirow{3}{*}{$\begin{array}{l}\text { Norma } \\
\text { Standard }\end{array}$} & \multicolumn{3}{|c|}{$\begin{array}{l}\text { Nazwa (symbol) i zakres frakcji uziarnienia [mm] } \\
\text { Particle size fraction (symbol), range of particle sizes }\end{array}$} & \multirow{3}{*}{$\begin{array}{l}\text { Nazwa gruntu, symbol } \\
\text { Soil name, symbol }\end{array}$} \\
\hline & \multicolumn{3}{|c|}{$\begin{array}{l}\text { Sklad granulometryczny wg analizy areometrycznej [\%] } \\
\text { Particle size distribution acc. to hydrometer analysis }\end{array}$} & \\
\hline & \multicolumn{3}{|c|}{$\begin{array}{l}\text { Sklad granulometryczny wg analizy mikroagregatowej [\%] } \\
\text { Particle size distribution acc. to microaggregate analysis }\end{array}$} & \\
\hline \multirow{3}{*}{ PN-B-02480 (1986) } & $\begin{array}{l}\text { piaskowa }\left(\mathrm{f}_{\mathrm{p}}\right) / \text { sand } \\
2,0-0,05\end{array}$ & $\begin{array}{c}\text { pyłowa }\left(\mathrm{f}_{\pi}\right) / \text { silt } \\
0,05-0,002\end{array}$ & $\begin{array}{l}\text { iłowa }\left(\mathrm{f}_{\mathrm{i}}\right) / \text { clay } \\
\quad \leq 0,002\end{array}$ & - \\
\hline & 27 & 42 & 31 & $\begin{array}{c}\text { ił/glina zwięzła } \\
\text { clay/clayey loam } \\
\mathrm{I} / \mathrm{G}_{\mathrm{z}}\end{array}$ \\
\hline & $12(-15)^{*}$ & $62(+20)$ & $26(-5)$ & $\begin{array}{c}\text { glina pylasta zwięzła } \\
\text { clayey silty loam } \\
\mathrm{G}_{\pi z}\end{array}$ \\
\hline \multirow{3}{*}{ PN-EN ISO 14688} & $\begin{array}{l}\text { piasek }(\mathrm{Sa}) / \text { sand } \\
2-0,063\end{array}$ & $\begin{array}{l}\text { pył }(\mathrm{Si}) / \text { silt } \\
0,063-0,002\end{array}$ & $\begin{array}{l}\text { ił }(\mathrm{Cl}) / \text { clay } \\
\quad \leq 0,002\end{array}$ & - \\
\hline & 21 & 48 & 31 & $\begin{array}{c}\text { ił z piaskiem i pyłem/ } \\
\text { ił z pyłem } \\
\text { sandy silty clay/silty clay } \\
\text { sasiCl/siCl }\end{array}$ \\
\hline & $9(-12)$ & $65(+17)$ & $26(-5)$ & $\begin{array}{l}\text { ił z pyłem } \\
\text { silty clay } \\
\text { siCl }\end{array}$ \\
\hline
\end{tabular}

* (-15) - zmiana zawartości frakcji mikroagregatowych w stosunku do analizy areometrycznej.

$*(-15)$ - change in the content of microaggregate fractions in comparison to the hydrometer analysis. 


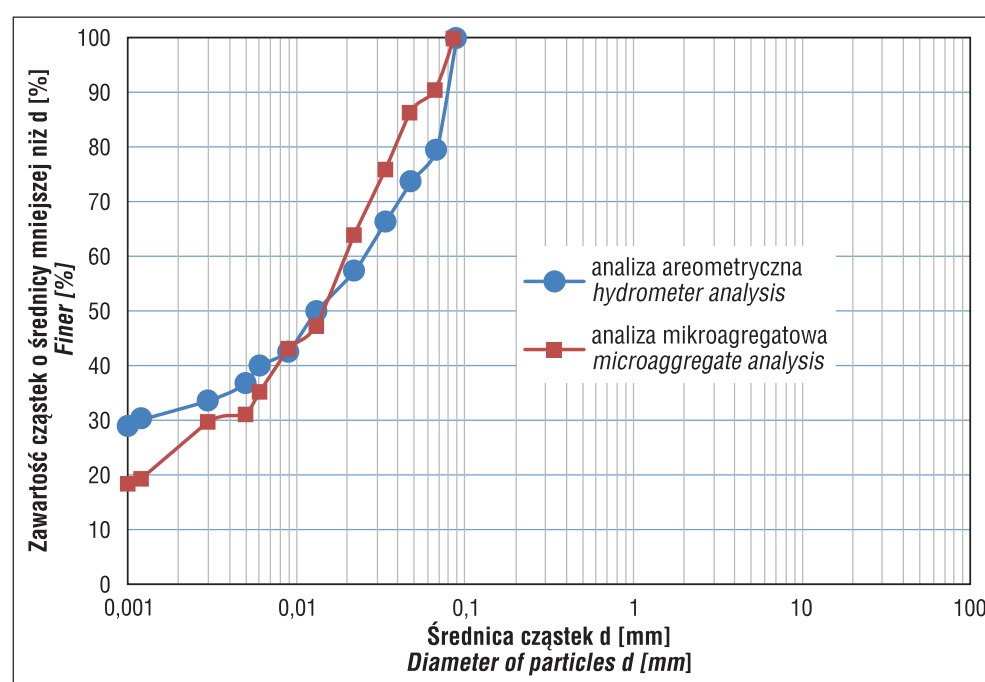

Ryc. 3. Krzywe uziarnienia mady naturalnej

Fig. 3. Particle size distribution curves of natural mud

Tab. 4. Porównanie klasyfikacji granulometrycznej próbek mad naturalnych wg PN-B-02480 (1986), PN-EN ISO 14688-2:2006/Ap2:2012 oraz Tarnawskiego (2017)

Table 4. Comparison of the granulometric classification of the natural mud samples acc. to PN-B-02480 (1986), PN-EN ISO 14688-2: 2006/Ap2: 2012 and Tarnawski (2017)

\begin{tabular}{|c|c|c|c|}
\hline \multirow{2}{*}{$\begin{array}{l}\text { Metoda badania } \\
\text { Testing method }\end{array}$} & \multicolumn{3}{|c|}{$\begin{array}{l}\text { Nazwa i symbol gruntu } \\
\text { Soil name and symbol }\end{array}$} \\
\hline & PN-B-02480 (1986) & $\begin{array}{c}\text { PN-EN ISO } \\
\begin{array}{c}\text { 14688-2:2006/Ap2: } \\
2012\end{array} \\
\end{array}$ & Tarnawski (2017) \\
\hline $\begin{array}{l}\text { Analiza } \\
\text { areometryczna } \\
\text { Hydrometer } \\
\text { analysis }\end{array}$ & $\begin{array}{c}\text { ił/glina zwięzła } \\
\text { clay/clayey loam } \\
\mathrm{I}_{\mathrm{z}}\end{array}$ & $\begin{array}{c}\text { ił z piaskiem } \\
\text { i pyłem/ił z pyłem } \\
\text { sandy silty clay/ } \\
\text { silty clay } \\
\text { sasiCl/siCl }\end{array}$ & $\begin{array}{c}\text { ił/glina zwięzła } \\
\text { clay/clayey loam } \\
\mathrm{Cl} / \mathrm{sasiCl}\end{array}$ \\
\hline $\begin{array}{l}\text { Analiza } \\
\text { mikroagregatowa } \\
\text { Microaggregate } \\
\text { analysis }\end{array}$ & $\begin{array}{c}\text { glina pylasta } \\
\text { zwięzła } \\
\text { clayey silty loam } \\
\mathrm{G}_{\pi z} \\
\end{array}$ & $\begin{array}{l}\text { ił z pyłem } \\
\text { clay with silt } \\
\text { siCl }\end{array}$ & $\begin{array}{l}\text { ił pylasty } \\
\text { silty clay } \\
\text { siCl }\end{array}$ \\
\hline
\end{tabular}

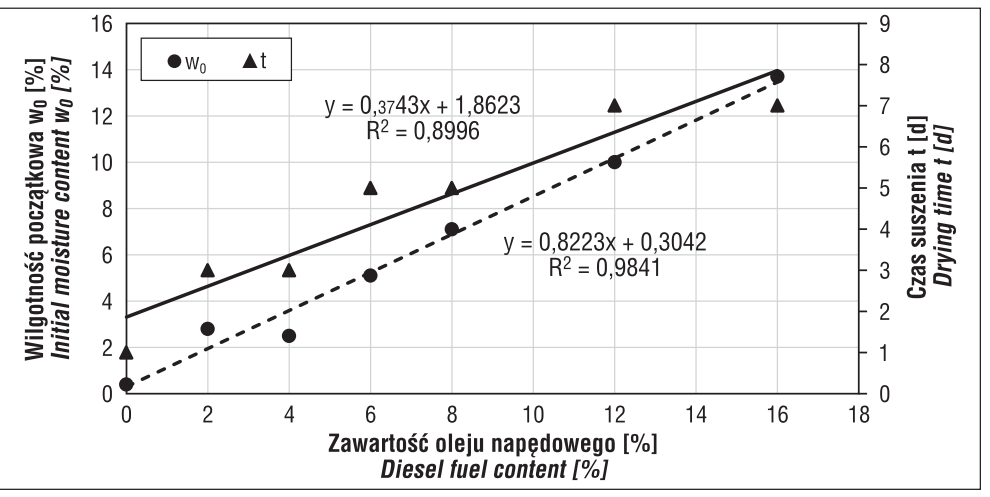

Ryc. 4. Wilgotność początkowa i czas suszenia próbek gruntu zanieczyszczonego ON

Fig. 4. Initial moisture content and drying time of soil samples contaminated with $\mathrm{ON}$

frakcji odczytanych wg standardu europejskiego wykazuje $6 \%$ wzrost frakcji pyłowej, a spadek piaskowej w stosunku do normy PN-B-02480 (1986), co wynika z różnicy w wymiarze ziarna na granicy frakcji pyłowej i piaskowej (tab. 3). Porównanie wyznaczonych nazw z propozycją harmonizacji obu systemów klasyfikacyjnych przedstawioną przez Tarnawskiego (2017) nie wykazuje zgodności w zakresie nazwy gruntu wyznaczonej metodą areometryczną (tab. 4). Przedstawione wnioski wskazują, że trudności z harmonizacją nazw gruntów wg obu systemów mogą się pojawiać tam, gdzie skład granulometryczny gruntu leży blisko lub na granicy klas.

\section{Uziarnienie past gruntowych zanieczyszczonych olejem napędowym}

Badania uziarnienia past gruntowych zanieczyszczonych ON obejmowały w pierwszym kroku oznaczenie ich wilgotności początkowej po 4-miesięcznym okresie homogenizacji. Stwierdzono, że dla próbek o zawartości $0-8 \%$ ON wilgotność początkowa gruntu jest o ok. 1\% niższa niż wynikająca ze stopnia zanieczyszczenia (zawartości procentowej ON w próbce), a dla próbek o zawartości 12 i 16\% ON o ok. 2\% (ryc. 4). Różnice te wskazują na pozostałość węglowodorów zaadsorbowanych na powierzchni szkieletu gruntowego, które nie uległy odparowaniu w procesie suszenia $\mathrm{w} 105^{\circ} \mathrm{C}$. Ponadto w badaniu zaobserwowano, że czas suszenia gruntu do momentu uzyskania stałej masy wydłuża się wraz ze wzrostem zawartości ON (ryc. 4). Dla próbki referencyjnej 0\% ON czas suszenia wyniósł jedną dobę, przy zanieczyszczeniu 2 i 4\% ON czas wydłużył się do 3 dni, a dla 6 i $8 \%$ ON suszenie trwało 5 dni. W przypadku 12 i $16 \%$ ON próbkę należało suszyć 7 dni.

Stwierdzono, że wraz ze wzrostem zawartości ON nastapił spadek zawartości frakcji piaskowej i iłowej, a wzrost zawartości frakcji pyłowej (tab. 5, ryc. 5). Zaobserwowany kierunek zmian jest analogiczny do wniosków wyciągniętych z analizy porównawczej wyników badań metodą areometryczną i mikroagregatową dla próbek mad naturalnych (niezanieczyszczonych, patrz tab. 3), ale jest spowodowany innymi procesami w obu przypadkach. Liniowy przebieg tych zależności o wysokim współczynniku korelacji może stanowić pomocne źródło referencyjne przy ocenie zmian uziarnienia gruntów o podobnej charakterystyce litologicznej i rodzaju zanieczyszczenia. Niezależnie od zastosowanej normy klasyfikacja granulometryczna badanego gruntu zmieniła się dla próbek 12 i 16\% ON. Według PN-B-02480 (1986) próbki 0-8\% zaklasyfikowano jako glina pylasta zwięzła $\left(\mathrm{G}_{\pi \mathrm{z}}\right)$, a próbki 12 i 16\% ON - glina pylasta $\left(\mathrm{G}_{\pi}\right)$. Według PN-EN ISO 146882:2006/Ap2:2012 próbki 0-8\% reprezentują ił z pyłem (siCl), a próbki 12 i 16\% ON - pył $\mathrm{z}$ iłem (clSi), co obrazuje zmiany procentowej zawartości frakcji uziarnienia w wyniku zanieczyszczenia ON. Zmiany stwierdzone w badaniach serii próbek zanieczyszczonych, można wiązać z efektem agregacji pokrytych węglowodorami cząstek iłowych, w wyni$\mathrm{ku}$ czego obserwuje się spadek zawartości $f_{i}$ i wzrost zawartości $\mathrm{f}_{\pi}$. $\mathrm{Z}$ drugiej strony, obecność węglowodorów prowadzi do osłabienia wiązań strukturalnych występujących w naturalnym gruncie i rozpadu większych agre- 
Tab. 5. Skład granulometryczny określony metodą mikroagregatową i nazwa próbek gruntu zanieczyszczonego ON wg PN-B-02480 (1986) i PN-EN ISO 14688

Table 5. Particle size distribution determined by the microaggregate analysis and the name of soil samples contaminated with ON acc. to PN-B-02480 (1986) and PN-EN ISO 14688

\begin{tabular}{|c|c|c|c|c|c|c|c|c|}
\hline \multirow{2}{*}{$\begin{array}{c}\text { Zawartość } \\
\text { oleju } \\
\text { napędowego } \\
\text { Diesel fuel } \\
\text { content } \\
\text { [\%] }\end{array}$} & \multicolumn{4}{|c|}{ PN-B-02480 (1986) } & \multicolumn{4}{|c|}{ PN-EN ISO 14688} \\
\hline & $\begin{array}{c}\text { Frakcja } \\
\text { piaskowa } \\
\text { Sand } \\
\mathrm{f}_{\mathrm{p}}[\%]\end{array}$ & $\begin{array}{c}\text { Frakcja } \\
\text { pylowa } \\
\text { Silt } \\
\mathrm{f} \pi[\%]\end{array}$ & $\begin{array}{c}\text { Frakcja ilowa } \\
\text { Clay } \\
\mathbf{f}_{\mathrm{i}}[\%]\end{array}$ & $\begin{array}{c}\text { Nazwa } \\
\text { i symbol gruntu } \\
\text { Soil name } \\
\text { and symbol }\end{array}$ & $\begin{array}{l}\text { Piasek } \\
\text { Sand } \\
\text { Sa [\%] }\end{array}$ & $\begin{array}{c}\text { Pyl } \\
\text { Silt } \\
\text { Si [\%] }\end{array}$ & $\begin{array}{c}\text { Il } \\
\text { Clay } \\
\text { Cl [\%] }\end{array}$ & $\begin{array}{c}\text { Nazwa } \\
\text { i symbol gruntu } \\
\text { Soil name } \\
\text { and symbol }\end{array}$ \\
\hline 0 & 18 & 59 & 23 & \multirow{5}{*}{$\begin{array}{l}\text { glina pylasta } \\
\text { zwięzła } \\
\text { clayey silty } \\
\text { loam } \\
\mathrm{G}_{\pi z}\end{array}$} & 17 & 60 & 23 & \multirow{5}{*}{$\begin{array}{l}\text { ił z pyłem } \\
\text { silty clay } \\
\text { siCl }\end{array}$} \\
\hline 2 & 18 & 59 & 23 & & 17 & 60 & 23 & \\
\hline 4 & 18 & 60 & 22 & & 17 & 61 & 22 & \\
\hline 6 & 18 & 61 & 21 & & 17 & 62 & 21 & \\
\hline 8 & 16 & 63 & 21 & & 14 & 65 & 21 & \\
\hline 12 & 14 & 69 & 17 & \multirow{2}{*}{$\begin{array}{c}\text { glina pylasta } \\
\text { silty loam } \\
\mathrm{G}_{\pi}\end{array}$} & 12 & 71 & 17 & \multirow{2}{*}{$\begin{array}{l}\text { pył z iłem } \\
\text { clayey silt } \\
\text { clSi }\end{array}$} \\
\hline 16 & 12 & 72 & 16 & & 9 & 75 & 16 & \\
\hline
\end{tabular}

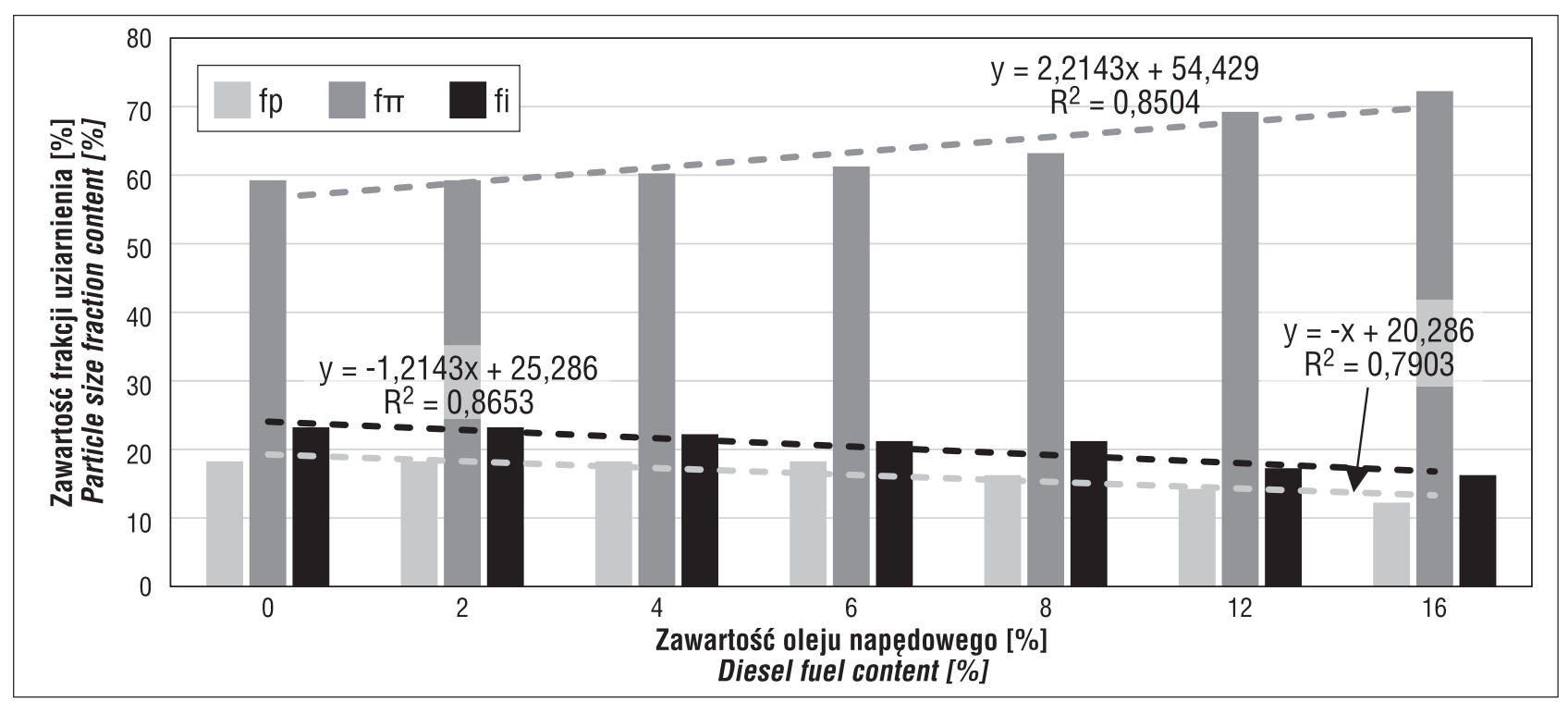

Ryc. 5. Skład granulometryczny próbek gruntu zanieczyszczonego ON oznaczony metodą mikroagregatową

Fig. 5. Particle size distribution of soil samples contaminated with $\mathrm{ON}$, determined by the microaggregate method

gatów frakcji piaskowej, co spowodowało spadek zawartości $\mathrm{f}_{\mathrm{p}}$. Problematyka zmiany uziarnienia gruntów zanieczyszczonych substancjami ropopochodnymi została poruszona zarówno w literaturze polskiej, jak i zagranicznej (np. Meegoda, Ratnaweera, 1995; Caravaca, Roldán, 2003; Korzeniowska-Rejmer, Izdebska-Mucha, 2006; Bobrowska, 2008; Izdebska-Mucha i in., 2011; Trzciński i in., 2015; Rajabi, Sharifipour, 2018; Izdebska-Mucha, Trzciński, 2021). Jednak należy podkreślić, że wrażliwość gruntu na zmiany jest silnie zależna od jego litologii, rodzaju zanieczyszczenia i metody pomiaru.

\section{Plastyczność past gruntowych zanieczyszczonych olejem napędowym}

$\mathrm{W}$ trakcie oznaczania granicy plastyczności $\left(\mathrm{w}_{\mathrm{P}}\right)$ sposób zachowania się próbek $0-16 \%$ ON podczas próby wałeczkowania był zróżnicowany (ryc. 6). Z próbek 0,2 i 4\% ON uformowano kulkę, a następnie wałeczek, który przy kolejnym wałeczkowaniu po osiągnięciu wilgotności granicy plastyczności pękał poprzecznie (ryc. 6A). Z próbki 6\% ON dało się uformować kulkę, a przy próbie wałeczkowania, wałeczek pękał podłużnie (ryc. 6B). Natomiast z próbek 8, 12 i 16\% ON nie dało się uformować kulki, gdyż pasta wykazywała cechy gruntu nieplastycznego (ryc. 6C, D, E). Na podstawie otrzymanych wartości $\mathrm{w}_{\mathrm{P}}$ stwierdzono, że wraz ze wzrostem zawartości oleju napędowego następuje wzrost, a następnie spadek wartości granicy plastyczności (ryc. 6F). Wartość $\mathrm{w}_{\mathrm{P}}$ próbki $0 \%$ ON wyniosła $25,0 \%$. W próbce $2 \%$ ON wzrost wartości granicy plastyczności był najwyższy i wyniósł prawie 4\%. Natomiast w próbkach 4 i $6 \%$ ON odnotowano spadek wartości granicy plastyczności o ponad $1 \% \mathrm{w}$ stosunku do próbki $2 \%$ ON, ale wzrost o prawie 3\% w stosunku do próbki $0 \% \mathrm{ON}$.

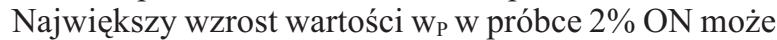
wynikać z podwyższonej sorpcji molekuł wody w węglowodorowo-mineralną strukturę pasty. Grunt nadal wykazywał właściwości plastyczne, o czym świadczą poprzeczne spękania podczas próby wałeczkowania. Wzrost zawartości oleju napędowego do 6\% doprowadził do częściowej utraty plastyczności i spoistości pasty (ryc. 6B). Podczas próby wałeczkowania próbka zachowywała się jak grunt mało spoisty, czego efektem było podłużne rozwarstwienie wałeczka. Taki wzrost zanieczyszczenia doprowadził do gromadzenia się na powierzchni elementów szkieletu wolnej fazy ON. Nagromadzenie oleju napędowego zainicjo- 


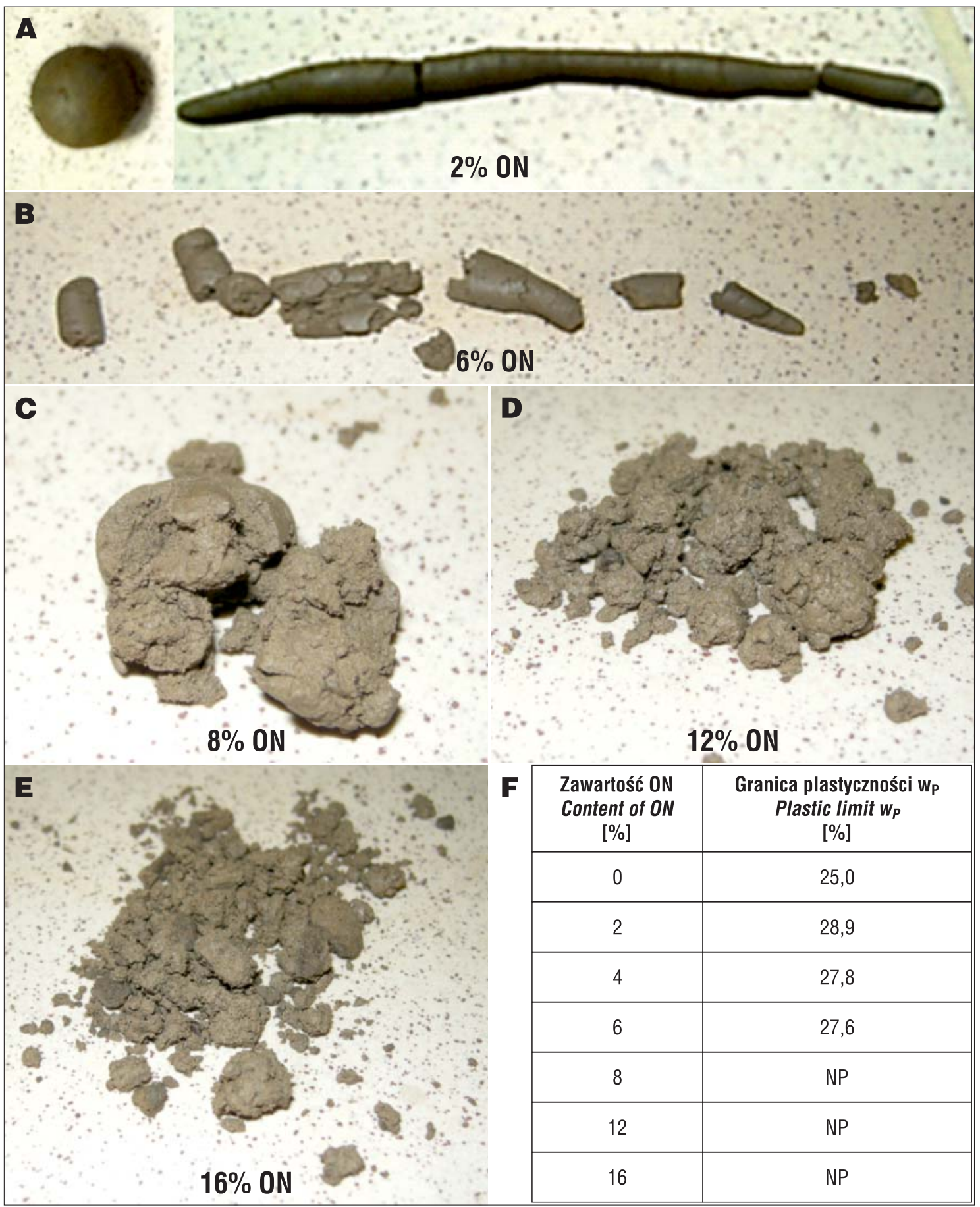

Ryc. 6. Wyniki oznaczenia granicy plastyczności próbek gruntu zanieczyszczonego ON: A - kulka i spękany poprzecznie wałeczek, B - wałeczek spękany poprzecznie i rozwarstwiony podłużnie, C, D, E - brak możliwości zrobienia kulki, F - wartości wP $(\mathrm{NP}$ - pasta nieplastyczna)

Fig. 6. Results of determination of the plastic limit of soil samples contaminated with ON: $\mathbf{A}-$ a ball and a thread with transverse cracks, B - a thread with both transverse and longitudinal cracks, C, D, E - the ball cannot be formed and the soil crumbles, $\mathbf{F}-\mathrm{w}_{\mathrm{P}}$ values (NP - non-plastic)

wało proces agregacji cząstek frakcji iłowej, co spowodowało wzrost zawartości frakcji pyłowej oraz spadek plastyczności (tab. 5). Dalszy wzrost zawartości ON i jego nadmiar nie zaadsorbowany przez szkielet mineralny generował gromadzenie się wolnego węglowodoru w przestrzeni pomiędzy elementami strukturalnymi, o czym świadczy ciemniejszy odcień gruntu (ryc. 2). Zawartość ON powyżej 6\% wywołała dalszy rozwój procesu agregacji cząstek frakcji iłowej (tab. 5) oraz całkowitą utratę plastyczności i spoistości gruntu, z którego nie dało się już uformować kulki (ryc. 6C-E).

W trakcie oznaczania granicy płynności $\left(\mathrm{w}_{\mathrm{L}}\right)$ zaobserwowano, że wzrastająca zawartość ON zmienia wygląd makroskopowy pasty (ryc. 7). Pasta nasycona tylko wodą jest jednolita i gładka (ryc. 7A). Powierzchnia zanieczyszczonych past staje się wizualnie bardziej chropowata i o większym połysku. Tendencja ta była najwyraźniej widoczna w próbce o najwyższej, 16\% zawartości ON (ryc. 7C). 


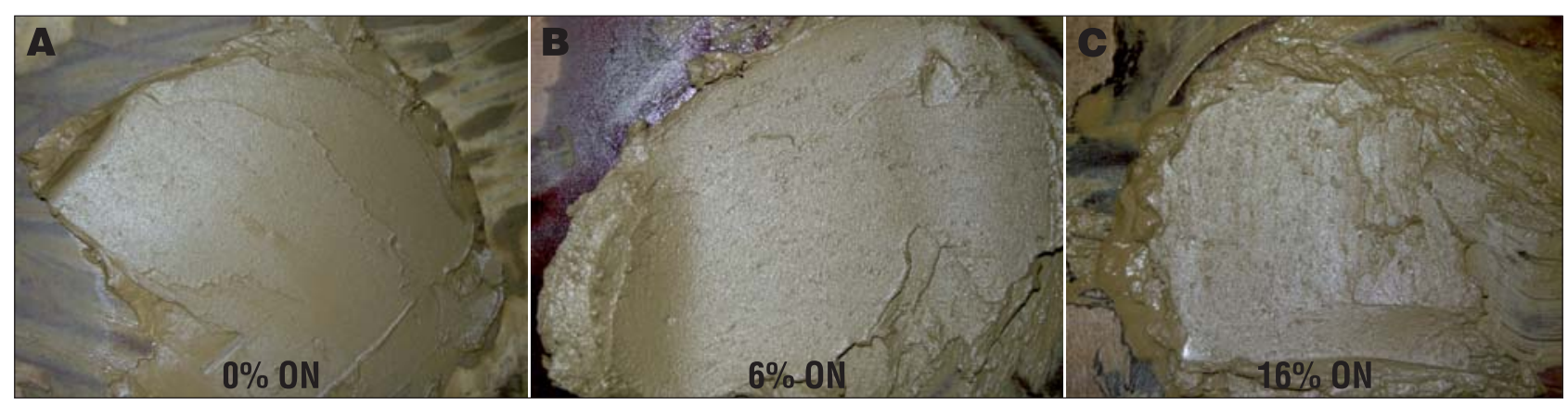

Ryc. 7. Wygląd past zanieczyszczonych ON w trakcie oznaczania granicy płynności (szczegółowy opis w tekście)

Fig. 7. The pastes of soil samples contaminated with ON, prepared for the determination of the liquid limit (see text for detailed description)

Tab. 6. Parametry obliczeniowe plastyczności próbek gruntu zanieczyszczonego ON

Table 6. Calculated parameters of plasticity of soil samples contaminated with ON

\begin{tabular}{|c|c|c|c|c|}
\hline $\begin{array}{c}\text { Zawartość oleju } \\
\text { napeqdowego } \\
\text { Diesel fuel content } \\
{[\%]}\end{array}$ & $\begin{array}{c}\text { Wskaźnik } \\
\text { plastyczności } \mathbf{I}_{\mathbf{P}} \\
\text { Plasticity index } \boldsymbol{I}_{\boldsymbol{P}}\end{array}$ & $\begin{array}{c}\text { Stopień plastyczności } \mathbf{I}_{\mathbf{L}} \\
\text { Liquidity index } \boldsymbol{I}_{\boldsymbol{L}} \\
{[\text { []] }}\end{array}$ & $\begin{array}{c}\text { Wskaźnik konsystencji } \mathbf{I}_{\mathbf{C}} \\
\text { Consistency index } \boldsymbol{I}_{\boldsymbol{C}} \\
{[-]}\end{array}$ & $\begin{array}{c}\text { Aktywność } \mathbf{A} \\
\text { Activity } \boldsymbol{A} \\
{[-]}\end{array}$ \\
\hline 0 & 29,7 & 0,15 & 0,85 & 0,96 \\
\hline 2 & 17,4 & 0,03 & 0,97 & 0,56 \\
\hline 4 & 18,7 & 0,09 & 0,91 & 0,60 \\
\hline 6 & 19,3 & 0,10 & 0,90 & 0,62 \\
\hline
\end{tabular}

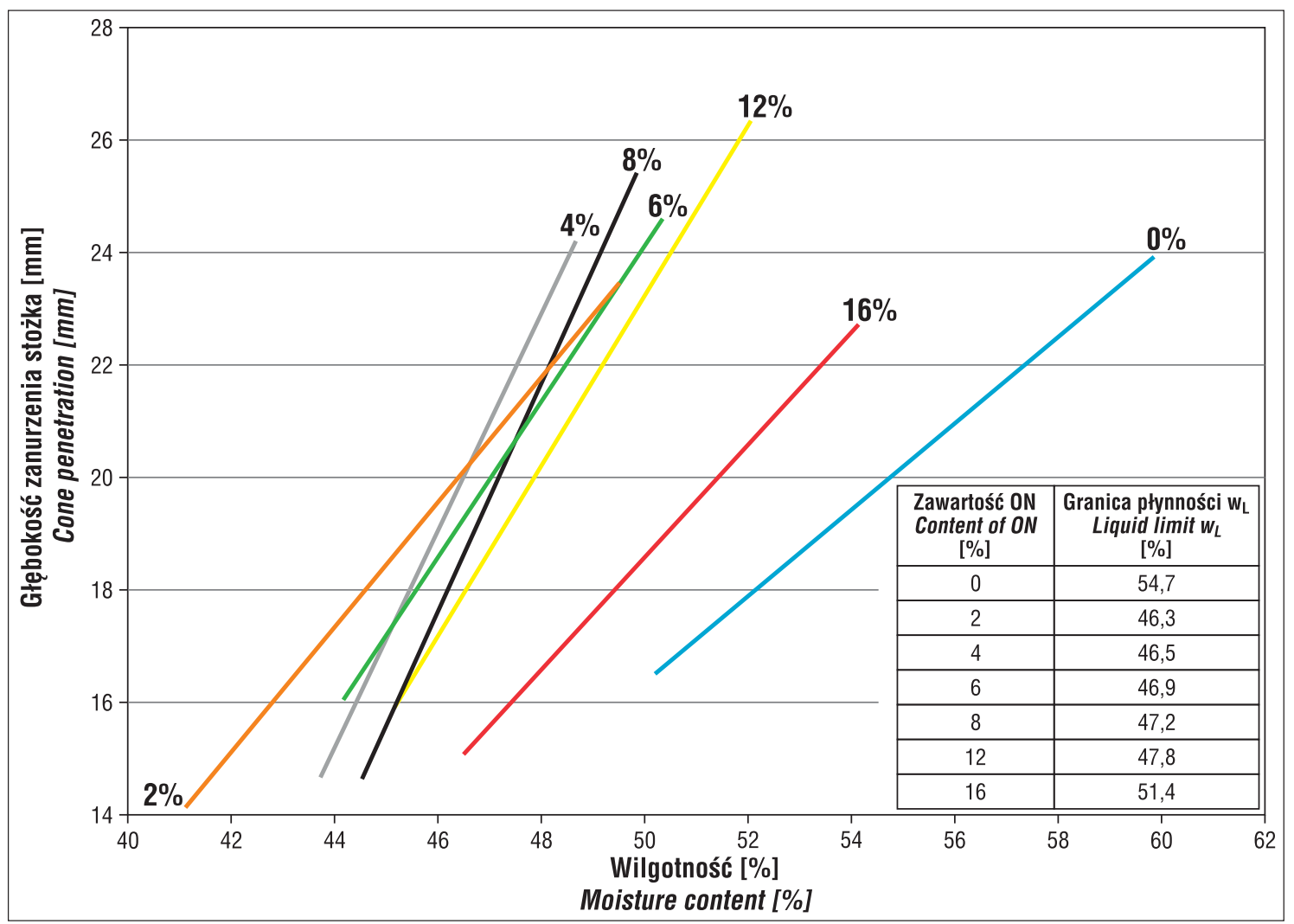

Ryc. 8. Wyniki badań granicy płynności próbek gruntu zanieczyszczonego ON

Fig. 8. Results of the liquid limit determination of soil samples contaminated with ON

Po dodaniu kolejnych porcji wody, podczas mieszania próbki nożem, ciecz ropopochodna gromadziła się jako lżejsza na powierzchni mieszanej pasty. Zaobserwowano również, że wzrost zawartości ON powodował szybsze upłynnianie pasty po dodaniu coraz mniejszych porcji wody, a w rezultacie głębsze zanurzanie stożka. Zjawisko to ilustruje wzrost kąta nachylenia linii służących do wyznaczania wilgotności granicy płynności (ryc. 8). Najniższą wartość kąta na- chylenia posiada pasta $0 \%$ ON, a po wzroście zanieczyszczenia, kąt nachylenia linii wzrasta. Wzrost zawartości wody dodawanej do pasty w celu określenia wilgotności granicy płynności powodował przyrost wody wolnej, która nie mogła zostać zaadsorbowana przez szkielet mineralny pokryty cząsteczkami węglowodorów. W trakcie wykonywania oznaczenia głębokości zanurzenia stożka, wysoka zawartość wody wolnej oraz nadmiar oleju napędowego 
w paście gruntowej wywoływały efekt mniejszego tarcia i większego poślizgu pobocznicy stożka w paście.

Grunt o zawartości $0 \%$ ON osiągnął najwyższą wartość granicy płynności - 54,7\% (ryc. 8). Dodatek oleju napędowego spowodował spadek wartości $\mathrm{w}_{\mathrm{L}}$. Największy spadek, o prawie $8,5 \%$, uzyskano w próbce $2 \%$ ON, a najmniejszy, o ponad 3\% - w próbce $16 \%$ ON. Wzrost zawartości oleju napędowego od 2 do $16 \%$ spowodował wzrost wartości $\mathrm{w}_{\mathrm{L}}$ o ponad $5 \%$.

Na podstawie oznaczonych w laboratorium parametrów zanieczyszczonych past gruntowych oraz gruntu naturalnego $\left(\mathrm{f}_{\mathrm{i}}, \mathrm{w}_{\mathrm{P}}, \mathrm{w}_{\mathrm{L}}, \mathrm{w}_{\mathrm{n}}\right)$ wyznaczono następujące parametry: $\mathrm{I}_{\mathrm{p}}, \mathrm{I}_{\mathrm{L}}, \mathrm{I}_{\mathrm{C}}, \mathrm{A}$ (tab. 6). Wartość parametrów podano jedynie dla próbek o zawartości 0, 2, 4 i 6\% ON, ponieważ przy wyższej zawartości zanieczyszczenia nie wyznaczono wartości $\mathrm{w}_{\mathrm{P}}$. Do obliczeń użyto wartości wilgotności naturalnej $\left(\mathrm{w}_{\mathrm{n}}\right)$, która wynosiła 29,5\% (tab. 2) oraz zawartości frakcji iłowej wyznaczonej dla próbki naturalnej w analizie areometrycznej, która wyniosła 31\% (tab. 3).

Pod wpływem wzrostu zanieczyszczenia następuje spadek wartości wskaźnika plastyczności $\left(\mathrm{I}_{\mathrm{P}}\right)$. Najwyższą wartość $\mathrm{I}_{\mathrm{P}}$ stwierdzono dla próbki $0 \% \mathrm{ON}-29,7 \%$, najniższą zaś dla gruntu o zawartości 2\% ON - 17,4\%. Zmiany wartości $\mathrm{I}_{\mathrm{P}}$ mają podobną tendencję jak dla wartości $\mathrm{w}_{\mathrm{L}}$, gdzie wzrost zawartości oleju napędowego w paście prowadzi do nieznacznego wzrostu wartości wskaźnika plastyczności. Spadek wartości granicy płynności i wskaźnika plastyczności na skutek zanieczyszczenia węglowodorami jest efektem, który obserwuje się w gruntach o smektytowym składzie frakcji iłowej (Kaya, Fang, 2000).

Wartość stopnia plastyczności $\left(\mathrm{I}_{\mathrm{L}}\right)$ waha się w zakresie $0,03-0,15$, przy czym najwyższą wartość stwierdzono dla próbki $0 \%$ ON, zaś najniższą dla próbki $2 \%$ ON. Dalszy wzrost zawartości ON powoduje wzrost $\mathrm{I}_{\mathrm{L}}$, a podobną tendencję obserwuje się dla wartości $\mathrm{w}_{\mathrm{L}}$ i $\mathrm{I}_{\mathrm{P}}$ (tab. 6, ryc. 8). Zawartość oleju napędowego w gruncie nie zmieniła stanu gruntu w zakresie klasyfikacji. Na podstawie otrzymanych wartości stopnia plastyczności i klasyfikacji wg PN-B02480 (1986) wszystkie próbki, bez względu na procentową zawartość zanieczyszczenia, znajdują się w stanie twardoplastycznym. Natomiast w zakresie przedziału stanu twardoplastycznego zmiany są znaczne. Zawartość 2\% ON powoduje skokową redukcję $\mathrm{I}_{\mathrm{L}}$, a konsystencja pasty zbliża się do stanu półzwartego i granicy skurczalności. Natomiast dla wyższych stopni zanieczyszczenia $\mathrm{ON}, \mathrm{I}_{\mathrm{L}}$ ponownie rośnie, a konsystencja gruntu zbliża się w kierunku $\mathrm{W}_{\mathrm{P}}$, wzrasta również plastyczność $\left(\mathrm{I}_{\mathrm{P}}\right)$, jednak wartości są wyraźnie niższe niż dla próbki $0 \%$ ON (tab. 6).

Wzrost zawartości oleju napędowego powoduje wzrost wartości wskaźnika konsystencji w stosunku do próbki niezanieczyszczonej. Najwyższą wartość $\mathrm{I}_{\mathrm{C}}$ otrzymano przy $2 \%$ zawartości ON, a dalszy wzrost zanieczyszczenia prowadzi do nieznacznej redukcji jego wartości. Tak jak w przypadku stopnia plastyczności, również w przypadku wskaźnika konsystencji zawartość oleju napędowego nie wpłynęła na zmianę stanu gruntu (tab. 6). Na podstawie otrzymanych wartości $\mathrm{I}_{\mathrm{C}}$ i klasyfikacji wg PN-EN ISO 14688-2:2018-05 wszystkie próbki, bez względu na procentową zawartość zanieczyszczenia, znajdują się w stanie twardoplastycznym.

Zanieczyszczenie olejem napędowym powoduje duży spadek aktywności gruntu. Najwyższa wartość aktywności, która posiada grunt niezanieczyszczony $(0 \% \mathrm{ON})$, wynosi 0,96 i klasyfikuje go wg Skemptona (1953) i Heada (1992) jako normalny. Wzrost zawartości ON zmniejszył wyraźnie aktywność gruntu do wartości $0,56-0,62$, co klasyfikuje go jako nieaktywny (tab. 6). Wyższa wartość aktywności zwiększa zdolność gruntu do wiązania wody, natomiast wzrost zawartości ON w gruncie zmniejsza znacznie jego zdolność do wiązania wody.

\section{PODSUMOWANIE}

Reasumując, z powyższych badań wynikają następujące konkluzje:

- badane mady charakteryzują się wysoką wartością wilgotności i porowatości oraz niską wartością gęstości objętościowej, sorpcji i pęcznienia;

- w składzie mineralnym występuje: $29 \%$ minerałów ilastych, w tym beidelit stanowi 22\%, a kaolinit 7\%; ok. $1,5 \%$ substancji organicznej; ok. 0,5\% węglanów oraz $69 \%$ kwarcu i innych składników nieaktywnych termicznie;

- wg PN-B-02480 (1986) badany grunt reprezentuje ił/glinę zwięzłą ( $\mathrm{I} / \mathrm{G}_{\mathrm{z}}$ ), a wg PN-EN ISO 14688-2:2006/ Ap2:2012 ił z piaskiem i pyłem/ił z pyłem ( $\mathrm{sasiCl} / \mathrm{siCl}$ );

- analiza mikroagregatowa próbek naturalnych wykazała spadek zawartości frakcji iłowej o 5\%, frakcji piaskowej o $12-15 \%$, a wzrost zawartości frakcji pyłowej o 17$20 \%$ w stosunku do wyników analizy areometrycznej;

- czas suszenia past gruntowych zawierających od 2 do $16 \%$ ON do momentu uzyskania stałej masy wzrasta wraz ze wzrostem stopnia zanieczyszczenia - dla próbki 2 i 4\% ON wynosił 3 dni, dla 6 i 8\% ON - 5 dni, dla 12 i 16\% ON - 7 dni, a wilgotność gruntu jest o ok. 1-2\% niższa niż zawartość procentowa $\mathrm{ON}$ w próbce;

- analiza mikroagregatowa zanieczyszczonych past wykazała, że wraz ze wzrostem zawartości ON nastąpił spadek zawartości frakcji piaskowej i iłowej, a wzrost zawartości frakcji pyłowej;

- obecność węglowodorów prowadzi do agregacji pokrytych węglowodorami cząstek minerałów ilastych oraz osłabienia wiązań strukturalnych występujących w naturalnym gruncie, co powoduje rozpad większych agregatów;

- grunt zanieczyszczony zachowuje właściwości plastyczne i spójność do 4\% ON, następnie staje się gruntem o cechach gruntu mało spoistego ( $6 \% \mathrm{ON})$, aby ostatecznie wykazywać cechy gruntu nieplastycznego i niespoistego $(8-16 \%$ ON);

- im wyższy stopień zanieczyszczenia, tym szybciej zostaje osiagnięta granica płynności i następuje upłynnienie gruntu;

- wszystkie zanieczyszczone pasty gruntowe wykazują redukcję wskaźnika plastyczności, stopnia plastyczności i aktywności oraz wzrost wskaźnika konsystencji w stosunku do próbki gruntu niezanieczyszczonego.

Autorzy składają podziękowania Recenzentom za czas poświęcony na merytoryczną analizę treści artykułu oraz za wniesienie cennych uwag, które przyczyniły się do polepszenia jego czytelności. Dziękujemy Mateuszowi Marszałkowi za pomoc w przygotowaniu fragmentu mapy Warszawy.

\section{LITERATURA}

BOBROWSKA M. 2008 - Wpływ bioremediacji na własności fizyczne wybranych gruntów z terenu Legnicy zanieczyszczonych substancjami ropopochodnymi. Zesz. Nauk. Państw. Wyż. Szk. Zaw. im. Witelona w Legnicy, 3: 17-26.

BS1377: Part 2:1990: 4.3, British standard methods of test for soils for civil engineering purposes, British Standards Institution, London.

CARAVACA F., ROLDAN A. 2003 - Assessing changes in physical and biological properties in a soil contaminated by oil sludges under semiarid Mediterranean conditions. Geoderma, 117: 53-61. 
FALKOWSKA E. 2005 -Związek akumulacji metali ciężkich w osadach facji powodziowej z morfologii doliny Wisły na odcinku od Annopola do Gołębia. Prz. Geol., 53 (8): 681-686.

FALKOWSKI E. 1967 - Ewolucja holoceńskiej Wisły na odcinku Zawichost-Solec i inżyniersko-geologiczna prognoza jej dalszego rozwoju. Biul. Inst. Geol. 198: 57-150.

FALKOWSKI E. 1970 - Historia i prognoza układu koryta wybranych odcinków rzek nizinnych Polski. Biul. Geol. Wydz. Geol. UW, 12: 5-121.

FALKOWSKI E. 1980 - Problemy genezy i interpretacji ukształtowania doliny środkowej i dolnej Wisły. Prz. Geol., 28 (6): 345-347.

FRANKOWSKI Z. 1980 - Metody ustalania własności gruntów słabonośnych na przykładzie utworów facji powodziowej Doliny Wisły koło Karczewa. Biul. Inst. Geol. 324.

GEOPROJEKT 1997a - Dokumentacja geologiczno-inżynierska do projektów budowlanego i wykonawczego budowy trasy Siekierkowskiej w Warszawie, cześć II: Odcinek trasy od km 3+000 do 5+000 z podporami mostu przez Wisłę i węzłem „Wał Miedzeszyński”, Warszawa. GEOPROJEKT 1997b - Dokumentacja geologiczno-inżynierska do projektów budowlanego i wykonawczego budowy trasy Siekierkowskiej w Warszawie, część IV: Odcinek trasy od km 5+000 do 8+144 z węzłami „Bora-Komorowskiego" i „Ostrobramska-Marsa”, Warszawa

GOŁEBIEWSKA A. 2011 - Uwagi krytyczne do klasyfikacji gruntów według normy PN-EN ISO 14688:2006. Biul. Państw. Inst. Geol., 446: 289-296.

GOŁEBIEWSKA A., WUDZKA A. 2006 - Nowa klasyfikacja gruntów według normy PN-EN ISO. Geoinż. Drogi Mosty Tunele, 4: 44-55.

GONTASZEWSKA A. 2010 - Geneza i geotechniczne aspekty występowania gruntów organicznych w dolinie Odry - przykład Słubic. Górn. Geol., 5 (4): 105-114.

GRABOWSKA-OLSZEWSKA B., SIERGIEJEW J.M. (red.) 1977 Gruntoznawstwo. Wyd. Geol., Warszawa.

HARSH G., PATEL A., HIMANSHU B., TIWARI P. 2016 - Effect of rate of crude oil contamination on index properties and engineering properties of clays and sands. Indian J. Sci. Technol., 9 (30): 1-4.

HEAD K.H. 1992 - Manual of soil laboratory testing. Vol. 1, Soil classification and compaction tests, London.

https://www.orlen.pl/content/dam/internet/orlen/pl/pl/dla-biznesu/produ kty/paliwa/olej-napedowy/Olej napedowy handlowy.pdf; 09.08.2021 IZDEBSKA-MUCHA D., SZYSZKO C., TRZCINSKI J. 2011 Właściwości geologiczno-inżynierskie i mikrostrukturalne glin lodowcowych zanieczyszczonych substancjami ropopochodnymi. Biul. Państw. Inst. Geol., 446: 459-468.

IZDEBSKA-MUCHA D., TRZCIŃSKI J. 2007 - Zmiany mikrostrukturalne gliny lodowcowej spowodowane zanieczyszczeniem olejem napedowym. Geologos, 11: 463-471.

IZDEBSKA-MUCHA D., TRZCIŃSKI J. 2011 - Właściwości geologiczno-inżynierskie i mikrostrukturalne glin lodowcowych zanieczyszczonych substancjami ropopochodnymi. Biul. Państw. Inst. Geol., 446 : 469-476.

IZDEBSKA-MUCHA D., TRZCIŃSKI J. 2021 - Clay soil behaviour due to long-term contamination by liquid petroleum fuels: microstructure and geotechnical properties. Bull. Eng. Geol. Environ., 80: 3193-3206.

KACZYŃSKI R. i in. 2009-2012 - Geologiczno-inżynierska ocena statycznego i dynamicznego zachowania sie gruntów wystepujacych w przekroju doliny Wisły w Warszawie na wysokości Mokotów-Ursynów. Projekt badawczy nr 3629/B/T02/2009/37.

KACZYNSKI R.R. 2017 - Warunki geologiczno-inżynierskie na obszarze Polski. Państw. Inst. Geol., Warszawa.

KAYA A., FANG H.-Y. 2000 - The effects of organic fluids on physicochemical parameters of fine-grained soils. Can. Geotech. J., 37: 943-950 KHAMEHCHIYAN M., CHARKHABI A.H., TAJIK M. 2007 - Effect of crude oil contamination on geotechnical properties of clayey and sandy soils. Eng. Geol., 89: 220-229.

KHOSRAVI E., GHASEMZADEH H., SABOUR M.R, YAZDANI H. 2013 - Geotechnical properties of gas oil-contaminated kaolinite. Eng. Geol., 166: 11-16.

KOCISZEWSKI R. 2003 - Dokumentacja geologiczno-inżynierska do projektu budowy osiedla Bluszczańska przy ul. Bartyckiej w m. Warszawa, Inw. 3347/2003 Arch. CAG PIG, Warszawa Kat. 12837 Arch. Urz. Marsz. Woj. Mazowieckiego, Warszawa, Nr CBDG Centralnej Bazy Danych Geologicznych 859622.

KOCISZEWSKI R. 2004 - Dokumentacja geologiczno-inżynierska do projektu budowy budynku A w osiedlu Bluszczańska II /II etap badań/ przy ul. Bartyckiej w Warszawie, Inw. 2083/2004 Arch. CAG PIG, Warszawa, Kat. 12876 Arch. Urz. Marsz. Woj. Mazowieckiego, Warszawa, Nr CBDG Centralnej Bazy Danych Geologicznych 890901.

KORZENIOWSKA-REJMER E., IZDEBSKA-MUCHA D. 2006 - Ocena wpływu zanieczyszczeń ropopochodnych na uziarnienie i plastyczność gruntów spoistych. Inż. Ochr. Środ., 9: 89-103.

KOWALSKA M., DUDKO-PAWŁOWSKA I., GAWLIK M. 2017 Wpływ uziarnienia i granic konsystencji na klasyfikację wybranych gruntów spoistych w świetle zmieniających się kryteriów normowych Prz. Geol., 65 (10/2): 707-716.
MEEGODA J.N., RATNAWEERA P. 1995 - Treatment of oil-contaminated soils for identification and classification. Geotech. Test. J., 18: 41-49.

MYSLINSKA E. 1980 - Inżyniersko-geologiczna charakterystyka mad doliny Wisły. Prz. Geol., 28 (6): 474-479.

MYŚLIŃSKA E. 1984 - Kryteria oceny inżyniersko-geologicznych właściwości mad. Kwart. Geol., 28: 143-162.

MYŚLIŃSKA E. 2001 - Grunty organiczne i laboratoryjne metody ich badania. Wyd. PWN, Warszawa.

MYŚLIŃSKAE. 2016-Laboratoryjne badania gruntów i gleb. Wydaw. UW. MYŚLIŃSKA E., HOFFMANN E., KULESZA-WIEWÓRA K. 1982 Zróżnicowanie litologiczne mad w wybranych odcinkach doliny Wisły. Prz. Geol., 30 (9): 474-479.

OLUREMI J.R., OSUOLALE O.M. 2014 - Oil contaminated soil as potential applicable material in civil engineering construction. J. Environ. Earth. Sci., 4: 87-99.

OSTAP M. 2010 - Wpływ zanieczyszczeń ropopochodnych na wybrane właściwości geologiczno-inżynierskie gruntu. Praca licencjacka, UW, arch.Wydz. Geol., Warszawa.

PIASKOWSKI A. 1984 - Właściwości sorpcyjne i powierzchnia właściwa polskich gruntów. Badania nad sorpcją błękitu metylenowego. Arch. Hydrotech., 31 (3): 297-314.

PN-B-02480:1986 - Grunty budowlane. Określenia, symbole, podział i opis gruntów.

PN-B-04481:1988 - Grunty budowlane. Badania próbek gruntu.

PN-EN 1997-2:2009 Eurokod 7 - Projektowanie geotechniczne - Część 2: Rozpoznanie i badanie podłoża gruntowego.

PN-EN ISO 14688-2:2006/Ap2:2012P Poprawka do Polskiej Normy. Badania geotechniczne-Oznaczanie i klasyfikowanie gruntów. Część 2: Zasady klasyfikowania. PKN, Warszawa.

PN-EN ISO 14668-1:2018-5 Badania geotechniczne - Oznaczanie i klasyfikowanie gruntów - Część 1: Oznaczanie i opis. PKN, Warszawa. RAJABI H., SHARIFIPOUR M. 2019 - Geotechnical properties of hydrocarbon-contaminated soils: a comprehensive review. Bull. Eng. Geol. Environ., 78: 3685-3717.

ROMAN G., ROMAN M., ROMAN M.G. 2016 - Warunki geologiczno-inżynierskie w dolinach rzecznych na przykładzie tarasu zalewowego Warty w rejonie Uniejowa. Prz. Nauk. Inż. Kształt. Środ., 25 (3): 366-378. ROZPORZĄDZENIE Ministra Transportu, Budownictwa i Gospodarki Morskiej z dnia 27 kwietnia $2012 \mathrm{r}$. w sprawie ustalania geotechnicznych warunków posadowienia obiektów budowlanych. Dz.U. z 2012 r. nr 81, poz. 463.

SALIMNEZHAD A., SOLTANI-JIGHEH H., SOORKI A.A. 2021 Effects of oil contamination and bioremediation on geotechnical properties of highly plastic clayey soil. J. Rock Mech. Geotech. Eng., 13 (3): 653-670.

SARNACKA Z. 1979 - Szczegółowa Mapa Geologiczna Polski w skali $1: 50$ 000, ark. Warszawa Wschód (524). http://bazadata.pgi.gov.pl/data/ smgp/arkusze skany/smgp0524.jpg, dostęp: 9.06.2021 r.

SARNACKA Z. 1980 - Objaśnienia do Szczegółowej Mapy Geologicznej Polski w skali $1: 50$ 000, ark. Warszawa Wschód (524). http://bazadata.pgi.gov.pl/data/smgp/arkusze txt/smgp0524.pdf, dostep: 9.06.2021 r SARNACKA Z. 1992 - Stratygrafía osadów czwartorzędowych Warszawy i okolic. Pr. Państw. Inst. Geol., 138.

SKEMPTON A.W. 1953 - The colloidal activity of clays. Proc. $3^{\text {rd }}$ Int. Conf. Soil Mech., Zurich, Vol. 1 Session 1/14

STAJSZCZAK P. 2021 - Zmiany właściwości filtracyjnych mieszanki gruntowej ił-piasek na skutek zanieczyszczenia produktami ropopochodnymi w aspekcie mineralnych barier izolacyjnych. Prz. Geol., 69 (1): $33-42$.

STEPIEŃ A. 1996 - Zależność parametrów gesstościowych od zawartości substancji organicznej dla gruntów okolic Białej Podlaskiej i Kurowa. Prz. Geol., 44 (8): 801-804.

SURYGAŁA J., ŚLIWKA E. 1999 - Wycieki ropy naftowej. Przemysł Chemiczny, 78: 323-325.

SZCZEPANKIEWICZ S. 1974 - Dolina Odry w kotlinie Raciborskiej zagadnienia akumulacji mady przemysłowej, Kraj. Symp. „Rozwój den dolinnych rzek niżowej części doliny Odry”, Wrocław-Poznań.

TARNAWSKI M. 2017 - Zharmonizowanie klasyfikacji gruntów spoistych według norm PN-EN ISO 14688:2006 i PN-86/B-02480. Prz. Geol., $65(10 / 2): 701-706$

TRZCIŃSKI J., WILIAMS D.J., ŻBIK M.S. 2015 - Can hydrocarbon contamination influence clay soil grain size composition? Appl. Clay Sci., 109-110: 49-54.

WÓJCIK E. 2003 - Wpływ ciśnienia ssania na przepuszczalność wybranych gruntów spoistych Warszawy. Rozprawa doktorska, UW, arch. Wydz. Geol.

WYRWICKI R. 1996 - Analiza derywatograficzna. [W:] Kościówko H., Wyrwicki R. (red.), Metodyka badań kopalin ilastych. Państw. Inst. Geol. IG, Warszawa-Wrocław: 56-76.

Praca wpłynęła do redakcji 15.06.2021 r.

Akceptowano do druku 23.08.2021 r. 